\title{
Interesse e legitimidade sob o crivo da efetividade em uma nova ordem processual
}

\author{
Interest and legitimacy under the analysis of effectiveness in a new procedural order \\ Interés y legitimidad bajo el cribado de la eficacia en un nuevo orden procesal
}

Recebido: 28/09/2021 | Revisado: 04/10/2021 | Aceito: 08/10/2021 | Publicado: 11/10/2021

\author{
Leonardo Peteno Magnusson \\ ORCID: https://orcid.org/0000-0001-9016-4620 \\ Universidade Paranaense, Brasil \\ E-mail: leonardopetenomagnusson@gmail.com \\ Diego José Baldissera \\ ORCID: https://orcid.org/0000-0001-9708-4084 \\ Universidade Paranaense, Brasil \\ E-mail: djbaldissera@gmail.com \\ Celso Hiroshi Iocohama \\ ORCID: https://orcid.org/0000-0002-0686-0330 \\ Universidade Paranaense, Brasil \\ E-mail: celso@prof.unipar.br
}

\begin{abstract}
Resumo
Objetivou-se, com este estudo, delimitar as linhas que circunscrevem os requisitos interesse e legitimidade, enquanto institutos de um novo sistema jurídico processual, que deu fruto ao Código de Processo Civil de 2015, o qual os contemplou expressamente como requisitos para postular em juízo. A partir da análise da construção teórica que instituiu estes elementos como categoria processual, registra-se que, por essência, são indissociáveis da estrutura processual fundamental ação, e constituem o vínculo através do qual se verifica a correspondência da situação afirmada em juízo à da vida. Destaca-se que a adoção desses requisitos como condições da ação pelo legislador do Código de Processo Civil de 1973 decorre da grande influência que Liebman exerceu sobre os processualistas brasileiros no século passado. Ao avançar, assenta-se um modelo de direito de ação teleológico, de natureza complexa, que, a partir de um processo instrumentalizado, assegura aos jurisdicionados o acesso à tutela jurisdicional adequada à garantia dos direitos substanciais. Ao desenvolver, consigna as formulações teóricas que se desenvolveram entre os juristas pátrios em torno da nova roupagem atribuída pelo legislador aos requisitos interesse e legitimidade. A partir do cotejo dessas construções, verifica-se que a dissonância entre os juristas perpassa pela natureza do exercício de cognição exercido pelo magistrado ao examinar os requisitos, mas esta em si é reflexo da verdadeira unicidade entre os teóricos, o aparelhamento dos institutos processuais, com o fito de constituir o processo como autêntico meio à prestação da tutela jurisdicional adequada.
\end{abstract}

Palavras-chave: Condições da ação; Direito de ação; Novo código de processo civil; Tutela jurisdicional.

\begin{abstract}
The paper intends to delimit the lines that circumscribe the requirements interest and legitimacy, while institutes of a new procedural legal system, that originated the 2015 Code of Civil Procedure, which expressly contemplated them as requirements to apply for a legal action. From the analysis of the theoretical construction that instituted these elements as a procedural category, it is recorded that, in essence, they are indissociable from the basic procedural structure of action, and constitute the bond through which the correspondence of the situation affirmed in judgment to that of life. It's emphasized that the adoption of these requirements as conditions of action by the legislator of the 1973 Code of Civil Procedure derives from the great influence that Liebman exerted on Brazilian proceduralists in the last century. In moving forward, it is based on a teleological right of action model, of a complex nature, which, through an instrumentalized process, ensures to the claimants the access to a proper judicial protection to the guarantee of substantial rights. In developing, it sets out the theoretical formulations that have developed among the patrician jurists around the new clothing assigned by the legislator to the requirements interest and legitimacy. From the comparison of these constructions, it is verified that the dissonance among jurists perpasses by the nature of the exercise of cognition exercised by the magistrate in examining the requirements, but this in itself is a reflection of the true unicity between the theorists, the grouping of the procedural institutes, with the aim of establishing the process as an authentic way to provide adequate judicial protection.
\end{abstract}

Keywords: Conditions of action; New code of civil procedure; Proper judicial protection; Right to action.

\section{Resumen}

El objetivo de este estudio fue delimitar las líneas que circunscriben los requisitos de interés y legitimidad, como institutos de un nuevo ordenamiento jurídico procesal, que dio origen al Código de Procedimiento Civil de 2015, que 
los contemplaba expresamente como requisitos para su aplicación en los tribunales. Del análisis de la construcción teórica que instituyó estos elementos como categoría procesal, se registra que, en esencia, son inseparables de la estructura procesal fundamental de la acción, y constituyen el vínculo a través del cual la correspondencia de la situación planteada en el tribunal con se verifica el de la vida. Es de destacar que la adopción de estos requisitos como condiciones de actuación por parte del legislador del Código de Procedimiento Civil de 1973 resulta de la gran influencia que ejerció Liebman sobre los estudiosos brasileños en el último siglo. Al avanzar, se establece un modelo complejo de ley de acción teleológica que, a partir de un proceso instrumentalizado, asegura a quienes tienen jurisdicción el acceso a una adecuada protección jurisdiccional para garantizar derechos sustanciales. Al desarrollarse, consigna las formulaciones teóricas que se desarrollaron entre los juristas brasileños en torno al nuevo vestuario atribuido por el legislador a las exigencias de interés y legitimidad. De la comparación de estas construcciones, se desprende que la disonancia entre juristas impregna la naturaleza del ejercicio del conocimiento que ejerce el magistrado al examinar los requisitos, pero esto en sí mismo es un reflejo de la verdadera unicidad entre los teóricos, la manipulación de los institutos procesales, con el objetivo de constituir el proceso como un medio auténtico para brindar una adecuada protección jurisdiccional.

Palabras clave: Condiciones de acción; Derecho de acción; Nuevo código de procedimiento civil; Tutela jurisdiccional.

\section{Introdução}

Quando da promulgação da Lei n ${ }^{\circ}$ 5.869, em 11 de janeiro de 1973, que implementou o Código de Processo Civil de 1973, não obstante os ventos já soprados advindos da Europa, os olhos da doutrina pátria ainda não estavam propriamente abertos, nem seus sentidos atentos à verdadeira revolução cultural em prol da bandeira da efetividade processual (Dinamarco, 2001).

No ordenamento jurídico brasileiro, tradicionalmente positivista, o papel do juiz, na sua atuação, era tão somente revelar a solução contida nas fontes, em especial a lei. Todavia, a superação histórica do positivismo abriu caminho para um conjunto amplo de ponderações acerca da função social do Direito, fortemente presente no processo moderno de constitucionalização, tendo como marco normativo a promulgação da Constituição Federal de 1988.

Nesse diapasão, com a socialização do direito constitucional, o texto do Código de Processo Civil de 1973 sofreu várias reformas, no ímpeto de instrumentalizar a efetivação das regras substanciais contempladas no ordenamento jurídico pátrio. Essas constantes alterações implementadas no codex processual revogado, particularmente aquelas ocorridas a partir da Emenda Constitucional $n^{\circ}$ 45, de 30 de dezembro de 2004, culminaram na elaboração de um novo Código envergado à regulação da atuação do órgão jurisdicional, cujo texto foi promulgado com a Lei n ${ }^{\circ} 13.105$, de 16 de março de 2015.

Não obstante posições dissonantes, como a de Saldanha (2010), a qual vê estreita relação entre as reformas processuais ocorridas no sistema processual brasileiro com interesses neoliberais, representados estes pela atividade paranormativa de agências transnacionais de fomento junto aos países periféricos, como o Banco Mundial, tem-se que o novo Código de Processo Civil foi elaborado com o desígnio de atender aos anseios dos jurisdicionados, mediante um modelo de processo que viabilize a prestação da tutela jurisdicional adequada e justa, sem perder de vista as garantias processuais decorrentes do devido processo.

Logo ao início, no art. $1^{\circ}$, o texto do Código de 2015 fixa que o Direito Processual Civil possui como norte mor os valores e normas fundamentais estabelecidos na Constituição da República Federativa do Brasil. Assim, a complexidade de institutos previstos pela nova codificação deve ser interpretada de modo a imprimi-los a maior efetividade, tendo como prisma a realização dos direitos subjetivos dos jurisdicionados, mas sem perder de vista todos os direitos e garantias processuais decorrentes do devido processo.

Entre os institutos incorporados pela nova codificação, que merecem especial enfoque, constam os elementos interesse e legitimidade, previstos nos artigos 17, 330, 337 e 485. Enquanto espécie do Código de Processo Civil de 1973, a sua fisionomia se orientava apoiada em concepção doutrinária específica, a qual, a partir de uma dogmática formal e conceitual, restringia a atuação positiva e criativa da jurisprudência e da doutrina. 
À vista disso, diante da necessidade de reexame das técnicas processuais, a partir do rompimento de dogmas estabelecidos no passado, o legislador, no novo Código, conferiu às espécies interesse e legitimidade nova roupagem. A nova forma atribuída viabilizou o desenvolvimento entre os juristas de formulações que, cada qual com suas particularidades, identificam nos requisitos as afeições adequadas à estruturação da tutela jurisdicional justa.

Justamente sob este panorama se presta a presente a análise. Tendo em vista a manutenção, pelo legislador, no texto do Código de Processo Civil de 2015, dos elementos interesse e legitimidade, que ao tempo do Código de 1973, sofriam reiteradamente críticas, a citar a abalizadíssima de Lacerda (1985) sobre a autonomia das condições da ação, é papel da doutrina e da jurisprudência corrente valorar os institutos. Esta atuação deve ser comprometida a adequá-los ao sistema jurídico processual contemporâneo, partindo da avaliação das experiências já vividas pelo direito pátrio.

\section{Metodologia}

O presente estudo procura delimitar as orientações da doutrina no que envolve os elementos interesse e legitimidade constantes da redação atual do Código de Processo Civil, pautado em um direito de ação com fundamento eminentemente teleológico. Para tanto, conta com a análise dos mesmos requisitos enquanto institutos do Código de Processo Civil revogado, transitando pelo modelo de direito de ação corrente a época e implementado na redação da codificação.

Para tanto, a pesquisa propõe a compreensão exploratória dos conceitos e proposições, relativos ao seu objeto, a partir da análise crítica do material bibliográfico disponível para o enfrentamento da problemática (Severino, 2007; Gil, 2009). Na construção dos conhecimentos a partir do encadeamento dos dados e informações depreendidos da literatura colhida, que é estruturado no processo discursivo do trabalho, o encandeamento do raciocínio formado, do ponto de vista de seus aspectos lógicos, privilegia-se o método dedutivo, em que as conclusões são alcançadas a partir de esforços lógicos que partem de argumentos pretéritos reconhecidos (Marconi \& Lakatos, 2010; Gil, 1999).

Dessa feita, parte-se da análise do engenho doutrinário que concebeu os elementos interesse e legitimidade como estão postos, e a sua sustentação histórica no direito positivo, a partir da análise da conjuntura corrente no século XX, quando da promulgação do Código de Processo Civil de 1973. Estabelecidas essas premissas, avança-se sobre a conjuntura atual que circunscreve a teoria da ação, que constitui pilar substancial do Código de Processo Civil em vigor, e, por conseguinte, norte para a interpretação dos institutos por ele contemplados. E por termo, debruça-se sobre as formulações estabelecidas no cenário jurídico brasileiro, acerca do interesse e legitimidade na contemporaneidade e no direito positivo posto a partir de 2015.

\section{Resultados e Discussão}

\subsection{A teoria eclética}

Os elementos interesse e legitimidade, denominados, em conjunto à possibilidade jurídica do pedido, como condições da ação, foram sistematizados por Liebman, como parte integrante, distintiva e fundamental de sua teoria sobre o direito de ação, a qual abarcou adeptos de incontestável autoridade em solo brasileiro, como relata Mesquita (1975), assim como foi integralmente adotada pelo Código de Processo Civil de 1973.

Diga-se que, a vinculação da efetiva existência do direito de ação ao preenchimento de determinados pressupostos não é adstrito à teoria Eclética. Durante o deslinde da celeuma jurídica, nunca acabada, em torno da natureza do direito de ação, os teóricos que se aventuraram a propor um modelo de direito de ação de características concretistas, acabaram por estabelecer uma condição intrínseca à própria existência do direito de ação, no que tange a imprescindibilidade de decorrer de um direito subjetivo anterior. Cita-se, por esse turno, o mestre de Liebman, Chiovenda e, o antecessor deste, Wach.

Atribui-se a Wach o mérito de haver demonstrado cabalmente a autonomia do direito de ação (Couture, 1946). Em sua teoria da ação como pretensão à tutela jurídica, relata Grinover (2011), Wach tem como objeto da atividade de cognição do 
juiz a existência concreta do direito à tutela jurídica, direito este que além de exigir a submissão do adversário, consiste na exigência do Estado desta prestação. Nessa toada, o objeto do processo expressa-se numa pretensão que consiste na exigência da prestação jurisdicional. Mas essa pretensão somente é satisfeita pela sentença favorável, o que decorre necessariamente do condicionamento da ação ao direito subjetivo material. Disso resulta a dependência da ação à concorrência de requisitos de direito material. Como bem analisa Gomes (1999, p. 31), estas condições seriam três:

a) a existência de um direito violado ou ameaçado de violação, sob pena de não haver legítimo interesse que deveria ser real, e não imaginário; b) a legitimação, ou seja, a necessidade de que o direito violado ou ameaçado fosse próprio; c) a possibilidade jurídica do pedido, ou a adequação do direito ao ordenamento jurídico concreto, materializado em fatos-tipo previamente determinados.

Noutra face, proclamando-se discípulo de Wach e recolhendo a parte substancial da teoria deste, Chiovenda (1942) formulou sua própria teoria da ação, sem abandonar as raízes concretistas apregoadas por Wach, e passou a definir o direito de ação como um "direito potestativo".

Haja vista que, em Chiovenda $(1942 ; 1943)$ a jurisdição se traduz na função do Estado, de caráter substitutivo, que tem como intento a realização no domínio dos fatos, nos exatos limites do direito da parte, da, preexistente, vontade concreta da lei, a qual se desenvolve através de uma complexa coordenação de atos que é o processo, a "ação é, portanto, o poder jurídico de dar vida à condição para a atuação da vontade da lei” (Chiovenda, 1942, p. 53). De mais a mais:

A ação é um poder que nos assiste em face do adversário em relação a quem se produz o efeito jurídico da atuação da lei. $\mathrm{O}$ adversário não é obrigado a coisa nenhuma diante desse poder: simplesmente lhe está sujeito. Com seu próprio exercício exaure-se a ação, sem que o adversário nada possa fazer, quer para impedi-la, quer para satisfazê-la. Sua natureza é privada ou pública, consoante a vontade da lei, cuja atuação determina, seja de natureza privada ou pública. (Chiovenda, 1942, pp. 53-54)

Mas, acentua Chiovenda (1942) que, para que o juiz declare existente e atue a vontade concreta da lei invocada pelo autor, que em seus termos corresponderia à um pronunciamento favorável, faz-se necessário que o direito em que se funda a demanda seja qualificado objetiva e subjetivamente. Bem assim, para afirmar, o juiz, a existência de uma vontade concreta da lei, que garante um bem ao autor, é imprescindível que: sobre a base da cognição realizada, ele considere existente tal vontade, ou seja, a existência efetiva de um direito; o juiz repute o direito, sobre o qual recai a lide, pertencente àquele que o faz valer e contrário àquele quem se faz valer e interesse daquele que demanda em conseguir o bem garantido pela lei e de consegui-lo por obra dos órgãos jurisdicionais.

Percebe-se, pelo exposto, que a delineação de requisitos para a provocação do exercício da jurisdição decorre, precisamente, do escopo que se tem a respeito da atuação do órgão jurisdicional e à posição do jurisdicionado diante deste. Todavia, não quer dizer que as condições da ação sistematizadas por Liebman como elementos caracterizadores de sua teoria sobre o direito de ação decorram, necessariamente, das lições dos mestres declinados, mas, sim, que implicam, em certa medida, em resquícios das teorias da ação de índole concretista constantes da teoria eclética formulada pelo autor, reflexo da tentativa de conciliar as doutrinas concreta e abstrata do direito de ação.

Liebman, em sua construção sobre o direito de ação, em ajuste à sua definição de tutela jurisdicional, intentou firmar sua orientação na zona fronteiriça entre aqueles que, de um lado, sustentam que a ação se sujeita ao efetivo reconhecimento do direito material por assim dizer, um direito à sentença favorável; e de outro, daqueles que visualizam a ação como um direito de provocar a atividade dos órgãos jurisdicionais e receber uma decisão qualquer que seja, com caracteres redondamente abstratos, fruto da capacidade de ser parte. Em suas letras: 
Entre essas duas correntes cabe uma posição intermédia, que se ajusta à definição, dada há pouco, da função jurisdicional. A ação, como direito de provocar o exercício da jurisdição, significa o direito de provocar o julgamento do pedido, a decisão da lide. É abstrata, porque tendo por conteúdo o julgamento do pedido inclui ambas as hipóteses em que este for julgado procedente ou improcedente, mas é subjetiva determinada, porque é condicionada à existência dos requisitos definidos como condições da ação. (Liebman, 1947, pp. 145-146)

Com isso, implica Liebman a negação ao caráter concreto da ação, haja vista que, da existência da ação, tem assegurado, a parte, o direito ao julgamento da lide; por assim dizer, à solução do conflito, efetivo ou virtual, dos pedidos contraditórios, sobre o qual o juiz é colocado a decidir. Contudo, não inclui a procedência da pretensão deduzida, a qual poderá ser acolhida ou rejeitada. Mas, ainda que decorra do genérico poder de agir, em si nada tem de genérico. "[...] Ao contrário, guarda relação com uma situação concreta, decorrente de uma alegada lesão a direito ou a interesse legítimo de seu titular [...]" (Liebman, 2005, pp. 199-200), de modo que da lide deve-se depreender determinados requisitos para poder ser julgada. Estes requisitos, justamente, dizem respeito às relações entre a lide e o conflito de interesses que a fez surgir, na medida em que aquela somente está apta a ser decidida se for adequada àquele conflito (Liebman, 1947).

Para a formulação de sua teoria, Liebman parte do princípio de que os juízes, como personificação da jurisdição, por natureza, não agem e não decidem por sua própria iniciativa. Nessa conformidade, se, por um lado, a iniciativa do processo, que se exerce demandando em juízo, constitui um ônus, ao mesmo tempo, é um direito da parte, que consiste no de retirar a jurisdição de sua inércia, “[...] com referência a uma situação jurídica em que ela é interessada, visando a obter do juiz a proteção de um interesse próprio ameaçado ou violado, ou a satisfação de um direito próprio que se afirma insatisfeito" (Liebman, 2005, p. 194).

Diante disto, é assegurado constitucionalmente a todos, indistintamente, o poder de agir, “[...] absolutamente genérico e indeterminado, inexaurível e inconsumível, não se ligando a qualquer situação concreta” (Liebman, 2005, p. 199). Nos dizeres de Neves (1997, p. 109), este poder consiste no “[...] direito cívico genérico de buscar o tribunal (sancionado na Constituição) que é o pressuposto prático, a garantia constitucional da possibilidade de qualquer um propor, caso por caso, as ações que, eventualmente, venha a competir-lhe".

Contudo, a diferença entre a teoria sobre o direito de ação sustentada por Liebman e as teorias puramente abstratas, cinge-se sobre o fundamento do autor de que:

[...] só tem direito à tutela jurisdicional aquele que tem razão, não quem ostenta um direito inexistente. Mas a única maneira de assegurar a quem tem razão a possibilidade de impor o reconhecimento desta em juízo consiste em permitir que todos tragam suas demandas aos tribunais, incumbindo a estes a tarefa de examiná-las e afinal acolhê-las ou rejeitá-las, conforme sejam procedentes ou improcedentes. (Liebman, 2005, p. 195)

Dessa feita, no magistério de Liebman (2005), coisa diferente é a ação. Ainda que esta se firme no direito constitucional de acesso aos tribunais, nada tem de genérico, uma vez que guarda relação a uma situação objetiva concreta, que funda a pretensão da parte. Por conseguinte:

[...] o direito de agir em juízo é realmente atribuído para a tutela dos próprios direitos e interesses legítimos, e isso significa que não pertenceria a quem postulasse tutela para direitos alheios. Eis uma primeira indicação que serve para individualizar a pessoa que, caso por caso, pode efetivamente agir em juízo: é o que se chama legitimação para agir. (Liebman, 2005, p. 199)

Em segundo lugar:

[...] como o direito de agir é concedido para a tutela de um direito ou interesse legítimo, é claro que existe apenas quando há necessidade dessa tutela, ou seja, quando o direito ou interesse legítimo não foi satisfeito como era devido, 
ou quando foi contestado, reduzido à incerteza ou gravemente ameaçado. Individualiza-se, com isso, a situação objetiva que justifica a propositura de uma demanda: é o que se chama interesse de agir. (Liebman, 2005, p. 199)

E, por seu turno, somente é titular do direito de agir aquele que tem a sua pretensão acolhida, ao menos, em tese, seja explicitamente ou implicitamente, no ordenamento jurídico, o que implica, por sua vez, na possibilidade de o juiz pronunciar a decisão pretendida pela parte, o que se chamou de possibilidade jurídica, posteriormente inserida na categoria do interesse de agir (Liebman, 1947).

Malgrado idôneas críticas, a cisão realizada por Liebman, do direito de ação, um com assento constitucional e outro na legislação, recebeu grande acolhida no ambiente jurídico pátrio, a citar Alvim (1990), o qual visualizava uma ação com caracteres genéricos e, portanto, incondicionado, sediada no direito constitucional e outra, que tem como pressuposto o direito constitucional, mas conexo a uma pretensão de direito material, e, por isso, sujeito a condições.

Dito isso, para Liebman, o direito de ação se traduz em um direito subjetivo processual, de afeições instrumentais, posto que no antecedente consiste no direito à jurisdição. Mas que, também, no subsequente, assegura à parte o direito aos meios necessários à garantia de suas razões, através do processo, e, por conseguinte, a solução da lide levada a apreciação do órgão jurisdicional, que, no processo de cognição, é realizado pela sentença de mérito, seja favorável ou não. Assim sendo, a ação também assume nuances abstratos, mas não genéricos, posto que a situação objetiva afirmada deve guardar relação com o resultado jurídico pretendido, o que pressupõe determinados requisitos, as condições da ação (interesse de agir, legitimação para agir e possibilidade jurídica do pedido).

De mais a mais, expressa o autor a ação como "[...] direito ao processo e ao julgamento do mérito [...]" (Liebman, 2005, p. 200). Disso resulta haver que a ação não é, em si, somente, direito à sentença de mérito e não implica, desde logo, no poder de exigi-la. Como bem afirma Dinamarco (2004), na ação per si estão inclusos poderes de iniciativa e participação, que asseguram à parte, além do direito de provocar o órgão jurisdicional a atuar, um feixe de situações jurídicas ativas, os quais possibilitam a prática de atos voltados a preparar o caminho a uma decisão favorável. Assistirá ao autor o poder de exigir o provimento de mérito em face do dever do juiz de emiti-lo, quando satisfeito o procedimento inerente à atuação do órgão jurisdicional e satisfeitos os pressupostos indispensáveis à prolação de um pronunciamento jurisdicional desta natureza.

Nessa toada, somente surgirá para o juiz a possibilidade (dever) de julgar a demanda, quando puder se considerar existente a ação. Ou seja, considerando que a existência da ação pressupõe a presença das denominadas condições da ação, o exercício do poder jurisdicional tem por natureza a presença dessas condições. Nessa guinada, define Liebman (2005, p. 203) as condições da ação como: "[...] condições de admissibilidade do julgamento da demanda, ou seja, como condições essenciais para o exercício da função jurisdicional com referência à situação concreta (concreta fattispecie) deduzida em juízo".

Os elementos interesse de agir, legitimação para agir e possibilidade jurídica, aqueles de ordem subjetiva e este de ordem objetiva, visam, nesta construção, retirar a generalidade da ação exercida, na medida em que deverá referir-se a um pressuposto fático que recebe guarida pela lei - representado esta pela condição da ação de ordem objetiva -, e conferir, propriamente, a ação ao verdadeiro titular do direito que se pretende em face do sujeito passivo, sob o escopo da factual necessidade da tutela pretendida - constituído pelas condições de ordem subjetiva (Gomes, 1999).

Assim, somente terão direito de ação aqueles que estiverem agasalhados, concomitantemente, pelo trinômio das condições da ação. A ausência de qualquer uma das condições inviabiliza o exercício de cognição do juízo para a apreciação do pedido do autor, seja para julgá-lo procedente ou improcedente. Isto é, a falta das condições da ação, ou ao menos uma delas, representa o que o autor denominou de carência de ação, devendo o juiz negar o julgamento do mérito e, então, declarar inadmissível a demanda (Liebman, 2005). 
À vista disso, os elementos interesse de agir, legitimação para agir e possibilidade jurídica do pedido, na doutrina do processualista italiano, não se tratam de condições para o exercício, mas, verdadeiramente, para a sua própria existência como direito ao processo (Dinamarco, 2004).

Deste quadro, implica que, para a doutrina eclética do direito de ação, o exercício do juiz de perquirir sobre as condições da ação não possui propriamente natureza jurisdicional. Aliás, isto decorre, justamente, de que, em Liebman, a atividade jurisdicional consiste na realização da justiça, mediante a aplicação do direito objetivo às relações humanas intersubjetivas, o que se realiza propriamente pela sentença de mérito. Em lição, o autor apresenta:

[...] no processo de cognição somente a sentença que decide a lide tem plenamente a natureza de ato jurisdicional, no sentido mais próprio e restrito. Todas as outras decisões têm caráter preparatório e auxiliar: não só as que conhecem dos pressupostos processuais, como também as que conhecem das condições da ação e que, portanto, verificam se a lide tem os requisitos para poder ser decida. Recusar o julgamento ou reconhecê-lo possível não é ainda, propriamente, julgar: são atividades que por si próprias nada têm de jurisdicionais e adquirem esse caráter só por serem uma premissa necessária para o exercício da verdadeira jurisdição. A ordem jurídica tende com a jurisdição ao fim de realizar-se praticamente. Esse fim é conseguido pela decisão de mérito, não pelo exame da existência das condições para que ela possa ser proferida. (Liebman, 1947, pp. 144-145)

Dessa feita, haja vista que a jurisdição tende à realização do direito objetivo diante a concessão ou negação da providência requerida, através de um julgamento de procedência ou improcedência das pretensões formuladas, sendo que o julgamento da lide processualizada pressupõe a ligação desta ao conflito de interesses presentes no plano objetivo, consubstanciado pelas condições da ação, “[...] não há nem ação nem exercício da função jurisdicional onde não estejam presentes as condições da ação (interesse para agir, legitimação e possibilidade jurídica)” (Mesquita, 1975, p. 38).

Note-se que, ao admitir integralmente o modelo em tela, que, ainda que o juiz verifique a ausência de alguma das denominadas condições da ação, terá havido processo. Isto porque, em termos de direito positivo, a carência de ação é chancela de sentença que extingue o feito sem análise do mérito. Disso resulta a existência de um processo sem ação, muito embora não iniciado de ofício (Oliveira, 2011). À idêntica conclusão se chega a partir da análise do seguinte trecho dos escritos de Liebman (2005, p. 203): "Toda decisão sobre as condições da ação é decisão sobre o processo, devendo aplicar a lex fori, seja qual for a lei que rege a relação controversa".

O sistema organizado por Liebman acabou por estabelecer três juízos a serem desenvolvidos pelo órgão julgador para a prestação jurisdicional que lhe é dever. Em primeiro, deverá o juiz perquirir sobre os requisitos necessários à formação e desenvolvimento válido e regular do processo - pressupostos processuais -, prosseguindo sobre as condições de existência do direito de ação - interesse de agir, legitimação para agir e possibilidade jurídica do pedido -, e, por derradeiro, estando formada a relação processual e assistindo a parte o direito à um pronunciamento de mérito, o juiz analisará a regra jurídica abstratamente prevista no ordenamento jurídico, em cotejo ao espectro fático delimitado na lide, conferindo a prestação jurisdicional adequada ao caso concreto. Sobre o trinômio em tela, tem Kazuo Watanabe obra de valor doutrinário indiscutível (da cognição no processo civil).

\subsection{O Código de Processo Civil de 1973}

Como efeito das tempestades políticas que assoavam a Europa pelos regimes totalitários, que culminaram no desenrolar da segunda grande guerra, Enrico Tullio Liebman lançou-se em 1940 às terras brasileiras. Em curta estada, regeu cursos em Minas Gerais e Rio de Janeiro, mas foi na Faculdade de Direito de São Paulo que estabeleceu suas raízes, onde permaneceu até quando regressou à Itália. A permanência do jurista italiano em solo brasileiro e sua influência no direito pátrio, se, por um lado, pode ser colhido através de seus escritos, traduzidos à língua oficial nacional ou nesta já redigidos, por 
outro, são relatados de forma memorável por seus discípulos, dentre os quais, por pertinência, citamos os relatos de Vidigal, Grinover e Buzaid.

Aponta Grinover (1986) que, além da grande influência pessoal que o autor exerceu sobre seus próximos, a partir de aprofundamento de discussões e inigualáveis lições, a majestosa produção científica do mestre italiano foi acolhida com grande entusiasmo pela comunidade jurídica, de modo que a sua influência se alargou pouco a pouco sobre processualistas de todo Brasil. Não obstante, em verdade, foi na cátedra paulista que Liebman foi abraçado. Apontam seus adeptos (Buzaid, 1977) que, no Brasil, antes dele, houveram grandes processualistas, mas não efetivamente escola. Depois do processualista italiano, estabeleceu-se o que se chamou de Escola Processual de São Paulo, “[...] cuja unidade metodológica e cuja doutrina remontam seguramente ao espírito criador e aglutinador de Enrico Tullio Liebman [...]”' (Grinover, 1986, p. 100).

A autoridade que o jurista italiano conseguiu estabeleceu a sua posição de forma incontestável, o que o colocou a salvo de grande parte das eventuais censuras que poderiam mover-lhe, sobremaneira por considerar a ação como direito, condicionado, à sentença de mérito (Mesquita, 1975). Neste panorama, Vidigal (1986), ao debruçar sobre o cenário brasileiro a respeito do direito de ação, deparou-se com uma doutrina processual em expressiva porção, alinhada ao conceito de Liebman, o que, ao realizar esta leitura, Mesquita (1975) caracterizou como doutrina dominante.

Sob este panorama, em concorrência à influência das ideias da processualística italiana, em 1972, foi encaminhado ao Congresso Nacional o Projeto de um novo Código de Processo Civil. Este projeto se construiu às mãos do Professor Catedrático da Faculdade de Direito da Universidade de São Paulo, Alfredo Buzaid, o qual o tinha redigido, a pedido, ainda em 1964. Discutido e aprovado, foi sancionado o Código de Processo Civil, como Lei no 5.869, em 11 de janeiro de 1973 por Emílio Médici, quando Buzaid já estava investido na função de Ministro da Justiça.

Buzaid foi um dos ensinados por Liebman que mais atestam as pompas que lhe são atribuídas. Refere-se a ele como “[...] professor no sentido mais completo da palavra" e, no que toca ao seu labor intelectual, expressa que "[...] todos têm, quanto à substância, a mesma erudição e, quanto à forma, o mesmo rigor, clareza e elegância de linguagem cristalina" (Buzaid, 1977, p. 133 e 135). Dessa feita, ao redigir o Código de Processo Civil de 1973, Buzaid (1977, p. 152) construiu "[...] um monumento imperecível de glória a Liebman, representando o fruto do seu sábio magistério no plano da política legislativa".

Nesse enfoque, no que tange ao direito de ação, haja vista a autoria do anteprojeto do Código de Processo Civil de 1973, um discípulo fiel de Liebman, “[...] natural que a vigente lei processual brasileira prevalecesse nitidamente a teoria eclética [...]" e, por conseguinte, "[...] prevendo como condições genéricas de toda e qualquer ação o interesse de agir, a legitimidade para a causa e a possibilidade jurídica do pedido (art. 267, VI)" (Freire, 2001, p. 76).

A conclusão diversa não se chega a partir da apreciação da sistemática do Código Buzaid, uma vez que este recepcionou, dogmaticamente, o instituto das condições da ação nos artigos $3^{\circ}$, 267, 295 e 301. Como bem expressa Dinamarco (2002, p. 38), também discípulo de Liebman, Buzaid, ao elaborar o texto que passaria a ser o Código de Processo Civil, já enquanto projeto, refletia “[...] posições seguras e coerentes quanto a certos pontos fundamentais, como a abstração da ação e as condições desta [...]".

A norma esculpida nos incisos II e III do caput do artigo 295 e inciso III do parágrafo único do mesmo artigo, bem como no inciso $\mathrm{X}$ do artigo 301 consiste na inaptidão da demanda deduzida pela parte em ter o mérito analisado quando houver o interessado como carecedor de ação. Por sua vez, o disposto no inciso VI do artigo 267 representa a consequência imediata da ausência de uma ou algumas das condições da ação - possibilidade jurídica, legitimidade das partes e o interesse processual -, que consiste na declaração de inadmissão da demanda e, por conseguinte, negação à análise da pretensão deduzida em juízo através do pedido, consubstanciado em sentença terminativa, ou seja, que extingue o processo sem julgamento do mérito.

À expressão carência de ação positivada no ordenamento jurídico (artigo 301, X) não se deve voltar os olhos com toda a extensão que a práxis forense lhe atribuiu, como sinônimo de não assistência da parte pelo direito substancial. Em verdade, o 
legislador se orientou pelo enfoque técnico-jurídico consagrado nos escritos de Liebman, o qual, em linhas gerais, consiste na ausência de uma ou algumas das condições da ação, que por sua vez representa a própria inexistência do direito de ação (Freire, 2001).

Portanto, tem-se que o modelo de direito de ação delineado nas linhas do Código de Processo Civil de 1973 corresponde, em seus próprios termos, ao elaborado por Liebman, ou seja, como um direito ao processo e ao provimento de mérito, mas condicionado ao implemento das condições da ação. Dito isso, os elementos interesse de agir e legitimação $a d$ causam, inserida, neste ponto, também a possibilidade jurídica, enquanto institutos do Código de Processo Civil de 1973, constituíam, propriamente, condições ligadas à efetiva existência do direito de ação, sem as quais ter-se-ia como inadmissível a pretensão deduzida pela parte.

Nada obstante, salienta-se, ainda, durante a vigência da legislação anterior, diante a ineficiência de um modelo que condiciona a própria existência do direito de ação, formaram-se orientações sem se distanciar da perspectiva de um trinômio de questões processuais, que tinham o instituto em tela como condições tão somente para o exercício da ação, através dos quais se permite que a parte chegue ao pronunciamento de mérito, a citar Grinover (1977) e Alvim (1990).

\subsection{O Código de Processo Civil de 2015 e o direito de ação}

De acordo com o Código de Processo Civil de 2015, em manifestação do princípio dispositivo, tem-se como proposta a ação com o requerimento inicial de tutela jurisdicional, mediante o protocolo da petição inicial (Art. 312), pela qual exerce o jurisdicionado uma das posições jurídicas inerentes ao direito de ação. Adverte, ademais, que, para postular em juízo considerando aqui a ação em seu sentido mais amplo, ou seja, como direito público subjetivo de titularidade do autor, réu e, eventuais, intervenientes, que se manifesta em momentos pré-processuais, endoprocessuais e pós-processuais (Nery Júnior e Nery, 2018) - é necessário ter interesse e legitimidade (Art. 17). A ausência de um desses elementos induz a negação do Estado-juiz a dar resposta à pretensão de tutela jurisdicional, mediante a extinção prematura do processo, sem apreciação do meritum causae (Art. 330, II e III; 337, XI, e 485, VI).

Há de considerar que o legislador não privilegiou a orientação aventada na doutrina brasileira quanto a supressão dos elementos interesse e legitimidade no direito legislado (Araújo, 2016). No entanto, é imperativo o devido apadrinhamento de que o legislador, verdadeiramente, conferiu nova roupagem ao instituto. A possibilidade jurídica do pedido não mais constitui subsídio autônomo que embaraça a análise do mérito. Outrossim, a expressão "condições da ação", antes prevista no inciso VI do artigo 267 da codificação revogada, não mais consta do rol de provimentos que não resolvem o mérito. Na mesma toada, a expressão "carência de ação", presente no artigo 301, X, do regime anterior, não mais consta entre as matérias prejudiciais alegáveis em sede de defesa.

O acerto inegável do legislador, no que pese o instituto em análise, em contrapartida à sistemática do codex revogado, cinge-se sobre a não adoção de um modelo doutrinário específico sobre a matéria. É papel da lei, enquanto fonte, estabelecer regras genéricas e abstratas, das quais o intérprete, em sua atuação positiva, a partir do cotejo do espectro de condições submetidas a ordem jurídica, realiza a concreção do direito. A doutrina exerce influência na criação do direito sobre dois panoramas: em primeiro, ela assume a condição de fonte direta, ao passo que introduz no mundo jurídico neologismos, novos conceitos, teorias e institutos; e, como efeito de sua atuação positiva, exerce o papel de fonte indireta, posto que favorece a atuação do legislador (Nader, 2001). Assim sendo, a estruturação de um direito positivo de índole eminentemente conceitualista, marca do código revogado, impõe à ciência uma atitude neutra, o que se deve evitar.

Por conseguinte, como bem afirma Medina (2014), membro da Comissão de Juristas nomeada pelo Senado Federal para elaboração do anteprojeto do texto que hoje vigora como Código de Processo Civil, na vigência do Código de Processo Civil de 2015, cabe à doutrina e à jurisprudência examinar os requisitos interesse e legitimidade como estão postos na nova 
codificação. Terão, nesse compasso, como tarefa adequá-los à essência da nova ordem processual, situando-os na categoria processual mais adequada, propriamente como condições da ação ou os aproximando aos pressupostos processuais ou ao mérito.

Com essa postura, a respeito da natureza dos elementos interesse e legitimidade na nova ordem jurídica processual implementada com o advento do Código de Processo Civil de 2015, emergiu no plano jurídico-doutrinário brasileiro três correntes. A primeira compreende que a lei continua a tratar legitimidade ad causam e interesse de agir como espécies de uma categoria processual intermediária, as condições da ação, a qual se situa entre os pressupostos processuais e o mérito da causa. A segunda identifica que as espécies passaram a encampar a categoria dos pressupostos processuais. A terceira, por derradeiro, que, ao identificar necessária correlação entre esses elementos e o mérito, os qualificam como requisitos ligados à apreciação do mérito, tendentes a viabilizar o exame dos pedidos.

A justa compreensão dos institutos processuais exige dos intérpretes uma atitude positiva, tendente à concreção do intento constitucional de proporcionar ao jurisdicionado um processo de resultados, apto a prestar satisfatoriamente a tutela jurisdicional (Theodoro Júnior, 2009). Assim sendo, o cotejo das orientações que se formaram acerca dos elementos interesse e legitimidade, enquanto institutos do Código de Processo Civil de 2015, reclama do jurista olhos voltados a um direito de ação tendente à efetivação dos direitos, a partir do processo justo. Nessa toada, passa-se à análise de um conceito de direito de ação que atenda ao seu fim colimado.

\subsubsection{A ação apta à satisfação dos direitos}

Se, historicamente, desempenhou papel importante no desenvolvimento da dogmática e evolução do direito processual civil o embate doutrinário a respeito da autonomia, concretude e abstração do direito de ação, na contemporaneidade, inevitável visualizar este direito sob outros prismas, “[...] que permitam uma maior aproximação das novas conquistas da teoria do Direito e da realidade do sistema jurídico, que tem a sua unidade e o seu fundamento na ordem constitucional" (Gonçalves, 1992, p. 143).

Sendo o processo uma instituição que instrumentaliza e legitima a atuação da jurisdição, o provimento jurisdicional há de ser construído processualmente, submetido aos princípios jurisdicionais e constitucionais. No quadro histórico da pósmodernidade, os princípios constitucionais do processo ultrapassam as margens de meros princípios procedimentais criados a esmo pela Constituição, implicam necessariamente em normas constitucionalmente construídas, que, através de garantias, asseguram o exercício pleno dos direitos, com foco aos fundamentais (Leal, 2008).

Concebe-se, assim, um processo voltado à instrumentalização e efetividade dos remédios processuais. Por conseguinte, a garantia de acesso à justiça, esculpida no art. $5^{\circ}, \mathrm{XXXV}$, da Constituição Federal, não assegura somente o acesso ao órgão jurisdicional. O direito de ação não é simples garantia de demanda, restrito a um requerimento inicial, mas, traduz-se, sim, em garantia de, diante qualquer lesão ou ameaça a direito, proteção e realização dos direitos subjetivos individuais, através de técnicas processuais adequadas (Marinoni, Arenhart \& Mitidiero, 2016).

Nessa toada, o princípio do acesso à justiça reflete duas finalidades básicas do sistema através do qual é assegurado aos cidadãos a faculdade de reivindicar seus direitos e ter resolvido os litígios pelo órgão jurisdicional. Em primeiro, destina-se a garantir a todos, igualmente, o acesso a este sistema, e, ato contínuo, garantir a proteção e satisfação da personalidade do jurisdicionado, a partir de resultados que sejam individual e socialmente justos (Cappelletti \& Garth, 1988).

Estendendo-se este raciocínio, a velha noção de devido processo legal, como garantia de mera técnica processual, no Estado Democrático de Direito, perde espaço para o que passou a se denominar devido processo constitucional, ou processo justo. A reafirmação do papel instrumental do processo na realização dos direitos substanciais, baseado no refinamento das 
técnicas e instrumentos processuais, reflete a devida preocupação de se estabelecer um sistema adequado e efetivo à satisfação dos direitos dos jurisdicionados (Theodoro Júnior, 2009).

Disso não resulta dizer que a técnica não mereça o esmero devido. A técnica constitui, em essência a ideia de processo. "É fundamental que o instrumento atue segundo técnica adequada e apta a possibilitar que os fins sejam atingidos", leciona Bedaque (2010, p. 26). Mas implica, necessariamente, em um cenário em que o processo é muito além de forma. "Toda a organização e estrutura desse mecanismo encontram sua razão de ser nos valores e princípios constitucionais por ele incorporados", prossegue Bedaque (2010, p. 26), concluindo que "a técnica processual, em última análise, destina-se a assegurar o justo processo, ou seja, aquele desejado pelo legislador ao estabelecer o modelo constitucional ou devido processo constitucional".

Nesse panorama, traduzindo-se a ação em uma garantia de índole fundamental, que assegura ao jurisdicionado o acesso à tutela jurisdicional adequada, a ser prestada pelo órgão jurisdicional, "o direito de ação consolida-se na compreensão de que todas as pessoas têm de obter a tutela efetiva dos juízes e tribunais, na concretização e exercício de seus direitos e interesses legítimos" (Baracho, 2004, p. 74).

Por isso, não é suficiente identificar na ação um direito de demandar, formular pretensão de tutela jurisdicional e colocar a jurisdição em movimento, ou, como em Liebman, ao provimento de mérito. A ação é, antes de tudo, um direito "[...] à tutela jurisdicional adequada, efetiva e tempestiva mediante processo justo" (Marinoni et al., 2016, p. 249), que assegure a parte uma decisão materialmente justa. Dessa forma, a partir do aparelhamento dos institutos procedimentais, apontam Marinoni et al. (2016), a construção de um sistema que garanta ao jurisdicionado tutela jurisdicional efetiva à proteção de sua esfera de direitos, reflete a estruturação de um direito de ação tendente à efetivação das diversas formas de tutela, assentado em técnicas processuais adequadas.

Nessa toada, volta-se à tutela jurisdicional com olhos muito além do resultado, mas, sim, sobre os meios que implicam na efetiva prestação jurisdicional (Dinamarco, 2002). Por conseguinte, a demanda, como ato jurídico de provocar a jurisdição a partir da formulação de pretensão jurisdicional, compõe parte de um “[...] complexo de posições jurídicas previstas ao longo de todo o procedimento que visa tendencialmente à tutela do direito mediante uma decisão justa e passível de adequada efetivação" (Marinoni et al., 2016, p. 250). Ademais, a ação não constitui pura e simplesmente um ato jurídico, mas sim uma condição permanente, que "[...] desenvolve-se com o objetivo de permitir o julgamento do mérito (do pedido) [...]”, mas nele não se esgota, "[...] ainda se mantém presente para exigir que os meios executivos da sentença de procedência propiciem a efetividade da tutela do direito material" (Marinoni et al.,2016, p. 250).

Didier Júnior (2016), a partir do pressuposto de que o direito de ação se trata de uma situação jurídica, compreende a complexidade de posições jurídicas inerentes a este direito como sendo uma infinidade de situações jurídicas. Neste complexo de situações jurídicas estão inseridas algumas de natureza pré-processual, como o direito de demandar e de escolher, quando possível, o procedimento. Instaurada a relação jurídica processual, surgem novas situações jurídicas, como o direito à tutela jurisdicional, direito à técnicas processuais adequadas para efetivar o direito afirmado, o direito à prova e o direito de recorrer. De mais a mais, aponta que, como corolário do direito de ação, ainda, incluem-se "[...] todas as situações jurídicas decorrentes da incidência do princípio do devido processo legal” (Didier Júnior, 2016, p. 287).

$\mathrm{Na}$ consecução de realizar os direitos substanciais dos cidadãos, o Estado atua sob dois escopos. Em primeiro, o Estado atua através do Poder Legislativo, a partir da estruturação de um processo que atenda às necessidades e seja adequada à tutela jurisdicional. Por outro, por intermédio do juiz, o Estado possui o papel de adaptar concretamente o processo, a partir do direito posto, com vistas a viabilizar a adequada e satisfativa prestação de tutela à esfera de direito dos jurisdicionados (Marinoni et al., 2016). Justamente por isso, a visualização do conteúdo complexo do direito de ação se trata de um grande avanço da ciência jurídica processual contemporânea (Didier Júnior, 2016). 
Através da identificação do conteúdo do direito de ação como direito fundamental, identifica-se, acertadamente, os limites da atuação do legislador na esfera infraconstitucional. "Limitações ao direito de ação podem existir, como sempre em tema de direito fundamental. Mas é preciso que tais limitações tenham justificação razoável, sob pena de inconstitucionalidade" (Didier Júnior, 2016, p. 287). Como exemplo de limitação da eficácia do direito de ação, cabalmente inconstitucional, cita-se a proibição a prestação de tutela antecipatória de forma indiscriminada contra a Fazenda Pública (Marinoni et al., 2016).

Por esses tantos, tem-se que, sem a visualização do fenômeno processual de forma dinâmica, ligada aos princípios e aos direitos fundamentais, e reestruturação dos institutos processuais com olhos à afinada tutela jurisdicional, a partir de uma postura ativa do Estado, e, neste ponto, inclui-se também a doutrina, os anseios da realização da justiça não se alcançam. Por conseguinte, o direito de ação, sob o ângulo teleológico, implica em um complexo de posições jurídicas que asseguram ao jurisdicionado - em um momento pré-processual - e aos sujeitos do processo - quando já formada a relação processual - o direito à tutela jurisdicional de forma adequada, efetiva, tempestiva e que observe todas as garantias decorrentes do devido processo constitucional.

\subsubsection{Os elementos interesse e legitimidade}

Imerso em uma ideologia que busca colocar em sintonia os institutos erigidos pelo Código de Processo Civil de 2015 com os ditames processuais prescritos pela ordem jurídica constitucional, sobre os elementos interesse e legitimidade reacenderam novas chamas. O que, no regime anterior, cuidava de celeuma superada, ainda que em termos de direito positivo, com a nova roupagem conferida pelo novo Código às espécies, debruça-se, novamente, a doutrina sobre a matéria, com vistas a imprimi-los a interpretação apta a concretizar a justiça.

Para parte da doutrina, teria, na sistemática do novo Código de Processo Civil, a categoria dos pressupostos processuais absorvido os requisitos interesse e legitimidade, que, em outros termos, constituíam categoria autônoma. Nessa orientação, Didier Júnior (2016) parte do princípio de que, na estrutura do Código de Processo Civil de 1973, são consagradas as condições da ação como categoria autônoma, ligadas à ação, sobre a qual, intermediária às questões de admissibilidade e de mérito, deveria o órgão jurisdicional se debruçar para produzir a tutela jurisdicional. Isso resulta do fato de ter o legislador ordinário contemplado textualmente, no inciso VI do artigo 267, a ausência de qualquer das condições da ação como circunstância de extinção do processo sem resolução do mérito, e, no inciso X, do artigo 301, mencionado a carência de ação como matéria de defesa.

Em cotejo do texto do novo Código de Processo Civil, com o do Código de 1973, constata Didier Júnior (2016) duas omissões bastante eloquentes, pelas quais conclui que inócua é a manutenção do conceito de condições da ação no processo civil brasileiro. Em idêntica observação chegou quando analisava o texto ainda enquanto projeto (Didier Júnior, 2011). Assim expõe o autor:

Primeiramente, não há mais menção "à possibilidade jurídica do pedido" como hipótese que leva a uma decisão de inadmissibilidade do processo. Observe que não há mais menção a ela como hipótese de inépcia da petição inicial (art. $330, \S 1^{\circ}, \mathrm{CPC}$ ); também não há menção a ela no inciso VI do art. 485 do CPC, que apenas se refere à legitimidade e ao interesse de agir; além disso, criam-se várias hipóteses de improcedência liminar do pedido, que poderiam ser consideradas, tranquilamente, como casos de impossibilidade jurídica de o pedido ser atendido. (Didier Júnior, 2016, p. 307-308)

A segunda alteração silenciosa seria ainda mais importante:

O texto normativo atual não se vale da expressão "condição da ação". Apenas se determina que, reconhecida a ilegitimidade ou a falta de interesse, o órgão jurisdicional deve proferir decisão de inadmissibilidade. Retira-se a menção expressa à categoria "condição da ação" do único texto normativo do CPC que a previa e que, por isso, 
justificava a permanência de estudos doutrinários a seu respeito. Também não há mais uso da expressão carência de ação. (Didier Júnior, 2016, p. 308)

Sustenta o jurista que a primeira alteração implementada pelo legislador representa a consagração de orientação já defendida a tempos pela doutrina, de que a impossibilidade jurídica do pedido é causa de decisão de mérito e não de inadmissibilidade, de modo que, ante a impossibilidade jurídica do pedido, deverá o juiz tê-lo como improcedente, distanciando-se da declaração de carência de ação (Didier Júnior, 2011). Na mesma toada, aponta Cunha (2011) que a não assistência, pelo ordenamento jurídico, de determinado pedido, induz a inexistência ao direito que a parte pede, de modo que esta é uma questão de mérito, e implica na negação, ao autor, de sua pretensão.

Nada obstante, Cunha vai além. Para o jurista (2011), somente a legitimidade extraordinária integraria o juízo de admissibilidade do processo. A legitimidade ordinária se trataria, na verdade, de questão de mérito. Nas palavras do autor: "Se o juiz conclui pela falta de legitimidade ordinária, o que está a decidir, em verdade, é pela ausência de titularidade do direito invocado, denegando a postulação formulada [...]", por conseguinte, o juiz “[...] declara não ter razão o autor, por não ser titular do direito; profere, enfim, sentença de improcedência" (Cunha, 2011, p. 234).

Já pela segunda modificação silenciosa, com a extinção no direito positivo das expressões condições da ação e carência de ação, pode-se extrair a conclusão de que não há mais essa categoria autônoma, de sorte que da ausência de interesse e legitimidade não é mais certo ter simplesmente a parte como carecedora de ação (Cunha, 2011). Situando-se, $a$ priori, esses elementos nas questões de admissibilidade, "a legitimidade ad causam e o interesse de agir passarão a ser explicados com suporte no repertório teórico dos pressupostos processuais” (Didier Júnior, 2016, p. 308).

Ambos os elementos, nesse enfoque, nos paradigmas arquitetados pelo Código de Processo Civil de 2015, passariam a integrar a exposição sistemática dos pressupostos processuais de validade. A legitimidade ad causam como pressuposto de validade subjetivo relativo às partes e o interesse como pressuposto de validade objetivo extrínseco. Por sua vez, a impossibilidade jurídica do pedido e legitimidade ordinária - neste ponto com certa resistência de Didier Júnior (2011), posto que, ainda que defenda essa orientação, não identificou que, necessariamente, o Código avançou nesse sentido - constituem propriamente matéria de mérito, razão pela qual implica a sua ausência na improcedência do pedido.

Ademais, é importante salientar que Didier Júnior (2016), na mesma medida que distanciou os elementos em destaque da construção das condições da ação, manteve a razão de ser daqueles requisitos atrelada a desta categoria processual. Nas letras do jurisconsulto, constituem, os requisitos em destaque, um filtro que impõe a existência de um vínculo efetivo entre a demanda e a situação jurídica afirmada.

Sob este fundamento, Medina (2016) também sustenta sua orientação sobre os requisitos em voga. Para ele, ainda que o direito de ação seja autônomo e abstrato em relação ao direito afirmado, deve guardar conexão com a relação jurídica de direito material alegada. "Sob esse prisma, os requisitos indicados pela lei (legitimidade e interesse processual) representam um elo de contato, mesmo que mínimo, entre a ação e o direito material [...]", porque “[...] a lide informada em juízo pelo autor há que incidir necessariamente em um bem da vida (pedido mediato), contrastando com a prestação jurisdicional pretendida do Estado-Juiz (pedido imediato)" (Medina, 2016, pp. 148-149).

Assim, para o processualista membro da Comissão de Juristas nomeada para a elaboração do texto do Código de Processo Civil de 2015, à vista dos requisitos interesse e legitimidade constituírem requisitos da demanda, esses são encartados entre os pressupostos processuais, “[...] já que a demanda é um dos pressupostos processuais” (Medina, 2016, p. 148).

Em outro sentido, Marinoni et al. (2016), ao analisar a postura do novo Código em escusar-se do nomen iuris condições da ação, bem como a advertência do legislador de que, para postular em juízo, é necessário ter interesse e legitimidade, concluem que esses elementos constituem puramente requisitos para a viabilização do exame do pedido de tutela jurisdicional, defeso à regulação conferida pela ordem jurídica anterior, como condições da ação. 
De acordo com os juristas, o novo Código de Processo Civil se afastou da regulação das condições da ação, peculiar do Código de 1973, na medida em que não fala mais em condições da ação. Apontam que, uma vez provocado o órgão jurisdicional, a partir do protocolo da petição inicial, a parte manifestou seu direito de ação, "de natureza processual totalmente abstrato e independente da efetiva existência do direito material alegado em juízo" (Marinoni et al., 2016, p. 207), e concluem que a jurisdição foi retirada de sua inércia e uma relação jurídica processual foi formada.

No que pese a não previsão do legislador ordinário da impossibilidade jurídica do pedido como categoria que obstaculiza o julgamento do mérito, os autores cadenciados divergem da orientação anteriormente exposta. Descrevem que essa categoria pode ser encartada na ausência de interesse de agir, em consonância à fração abalizadíssima da doutrina pátria, diante a omissão de Liebman dessa categoria na terceira edição de seu Manual (Marinoni et al., 2016).

Destacam os processualistas que a razão pela qual fez bem o novo Código em se omitir em arrolar legitimidade e interesse como condições da ação, situa-se na inexistência de lógica e utilidade em admitir sentença de extinção do processo sem julgamento do mérito pela ausência de "carência de ação", ao termo do processo, quando o Estado-juiz pode reconhecer o autor como não titular do direito material (legitimidade para a causa) ou que o autor não pode exigir o direito vindicado (Marinoni et al., 2016).

Nada obstante, na estrutura processual renovada, para os processualistas, os requisitos interesse e legitimidade não passariam a integrar o próprio mérito. No espectro enfincado pela nova codificação, ao delinear os provimentos que resolvem ou não o mérito, a evidenciação, pelo órgão jurisdicional, da ausência de legitimidade ou interesse processual foi inserida no campo da inviabilidade da emissão de provimento de mérito. De sorte que, a sentença que extingue o processo por ausência de interesse e legitimidade, por sua vez, apenas reconheceria o não preenchimento de requisitos necessários à apreciação do mérito, colocando termo ao processo sem ingresso na fase cognição sobre a situação jurídica material levada à apreciação do Estado-juiz (Marinoni et al., 2016).

Sob essa construção teórica, as então denominadas condições da ação "[...] somente podem ser requisitos para a viabilização do exame do pedido", guardando, assim, “[...] relação com o mérito [...]". De mais a mais, "tais requisitos são os primeiros degraus ligados à apreciação do mérito - e, nessa direção, para a tutela do direito" (Marinoni et al., 2016, p. 213).

A partir de ilação de ideias semelhante às até esse ponto examinadas, Wambier e Talamini (2016), por seu turno, deparam-se com um cenário em pontos semelhante ao observado, e, em outros, diverso. Como soma à conjuntura que neste trabalho se projeta, relevante destacar ao que os autores se referem como pressupostos de admissibilidade da tutela jurisdicional.

Para os processualistas, conquanto a ação possa ser exercida sem qualquer limitação, o caminho à apreciação da tutela jurisdicional pretendida reclama a concorrência dos requisitos interesse e legitimidade. "Ausente uma delas, fica bloqueado a via para a integral prestação da tutela, pois o juiz deve pôr fim ao processo sem resolução do mérito [...]" (Wambier \& Talamini, 2016, p. 218).

Disso há de se concluir que os requisitos interesse e legitimidade não integram o mérito, para mais quando evidenciados em concorrência ao panorama prescrito no art. 485 do novo Código. Sem embargo, ainda que essa categoria conduza à efetiva e eficaz instauração do processo e à obtenção da tutela jurisdicional, foi tratada pelo legislador ordinário da codificação vigente, destacadamente, em relação aos pressupostos processuais positivos e negativos (Wambier \& Talamini, 2016).

Por conseguinte, aludem os autores que, "em certa medida, adotou-se a concepção teórica que não vê maior relevância em distinguir os 'pressupostos processuais' das 'condições da ação', chamando-os todos de 'pressupostos de admissibilidade da tutela jurisdicional'" (Wambier \& Talamini, 2016, p. 219). Nesta categoria estariam inseridas, restritamente, as questões 
propriamente alheias ao mérito, sobre as quais deverá o magistrado se debruçar antes de ingressar no momento processual de análise da tutela jurídica pretendida.

Pelo que se delineou até esse ponto, evidencia-se que as construções em torno dos novos ares que o Código de Processo Civil de 2015 conferiu aos requisitos interesse e legitimidade, arquitetam-se, substancialmente, sobre dois aspectos. A extinção, em termos de direito positivo, das expressões condições da ação e carência de ação, e a não subsistência, na nova sistemática, da impossibilidade jurídica do pedido como categoria autônoma que obstaculiza a análise da pretensão de direito material deduzida.

Todavia, onda em sentido diverso tem força na doutrina. Ainda que entre alguns, em tom de lamentação, como Araújo (2016), a eliminação da possibilidade jurídica do pedido e das expressões condições da ação e carência de ação, não é suficiente para justificar o fim das condições da ação. "O art. 17 do CPC é fonte direta do trinômio e exige a demonstração do interesse e da legitimidade como requisitos da postulação e os vincula, por meio do art. 485, VI, como condições essenciais para a sobrevivência da ação" (Araújo, 2016, p. 343).

Sob este espeque, compreende Bueno (2018, p. 78) que:

[...] o CPC de 2015, ao preservar a legitimidade e o interesse (art. 17), manteve incólume o funcionamento daquelas categorias, no que é suficientemente claro o disposto no inciso VI do art. 485, isto é: quando o magistrado verificar que não há interesse e/ou nem legitimidade - e se, por qualquer razão, não for possível o saneamento do vício e/ou o seu esclarecimento -, ele não poderá proferir decisão relativa ao reconhecimento de quem faz jus à tutela jurisdicional ou, no jargão preservado pelo próprio CPC de 2015, de mérito. Muito pelo contrário, ele deve proferir decisão obstativa daquela finalidade, a chamada sentença terminativa, que não aprecia o mérito. É correto entender, portanto, que a extinção da categoria das condições da ação é mais nominal do que, é isto que realmente importa, substancial.

Asseveram aqueles que identificam esta orientação do Código atual, que a não previsão da impossibilidade jurídica do pedido como condição autônoma que obstrui a análise do pedido de tutela jurídica formulado, a rigor, representa a adoção, na íntegra, da doutrina de Liebman, da década de 1970. A impossibilidade jurídica seria um caso, na verdade, de falta de interesse de agir, na medida em que a exclusão precedente pelo ordenamento jurídico da tutela jurídica deduzida pela parte implica na ausência de qualquer utilidade da providência jurisdicional pretendida (Câmara, 2011).

Nessa sistemática, as condições da ação constituem requisitos constitutivos da ação, cujo exame deve ser realizado, individualmente em cada caso, preliminarmente à apreciação do mérito, em caráter prejudicial. Incumbe às condições, sob esse escopo, retirar a generalidade da ação e evidenciar a idoneidade do objeto sobre o qual a atividade jurisdicional do Estado perquirirá. Isso se dá pois importam, as condições, no cotejo do direito de ação concretamente exercido com a viabilidade abstrata da pretensão de direito material (Theodoro Júnior, 2017).

A ausência de qualquer uma das condições da ação, que passaram a ser somente interesse e legitimidade para agir, induz a negação do Estado-juiz de proferir resposta sobre o conflito de interesses material objeto da demanda, com a extinção da relação processual. Igualmente à inobservância dos pressupostos processuais, pois diante o não preenchimento dos pressupostos a relação jurídica processual não se aperfeiçoa adequadamente (Theodoro Júnior, 2017). Seriam, assim, os pressupostos processuais e as condições da ação, requisitos necessários à emissão de um provimento de mérito (Câmara, 2011).

Contudo, de acordo com Câmara (2011), a proximidade entre os pressupostos processuais e a categoria condições da ação, não retira desta categoria a heterogeneidade que lhe é natural. Isto porque, ainda que impliquem em juízo de admissibilidade do provimento de mérito, eles dizem respeito a distintos, e autônomos entre si, institutos fundamentais da teoria geral do processo.

No escólio de Thamay (2016), inserir os elementos interesse e legitimidade na conjectura dos pressupostos processuais determina a deturpação de dois institutos fundamentais do processo, o processo e a ação. Esses institutos somados 
à jurisdição, sem embargo de sua categorização como conceitos complementares, refletem afeições particulares do fenômeno processual. Na lição do jurisconsulto (2016, p. 1246), “[...] se há condições relativas ao processo, desde Büllow estudadas sob o nome de 'pressupostos processuais', é natural que também haja pressupostos da ação, as chamadas 'condições da ação"”.

Nessa perspectiva, ao passo que os pressupostos processuais se ligam com a existência e validade do processo, as condições da ação condizem com o exercício da ação. Por conseguinte, "os pressupostos processuais, em suma, põem a ação em contato com o direito processual, e as condições de procedibilidade põem-na em relação com as regras do direito material" (Theodoro Júnior, 2017, p. 160).

Como relevado oportunamente, para aqueles que se filiam à orientação em destaque, a ausência de uma ou algumas das, denominadas, condições da ação, representa a carência de ação pela parte, devendo o órgão jurisdicional negar a apreciação do mérito da causa. Mas, na sistemática atual, “[...] não quer dizer que, pelo fato do decreto de carência de ação, não tenha havido processo e exercício da função jurisdicional" (Theodoro Júnior, 2017, p. 160). Ocorre, como afirma o Autor (2017), apenas o encerramento prematuro da relação processual, antes de enfrentar o mérito, por não concorrem as condições técnicas.

Esta orientação é colhida de asseverada lição doutrinária. Nas palavras de Grinover (1977, p. 29):

[...] o fenômeno da carência de ação nada tem a ver com a existência do direito subjetivo afirmado pelo autor, nem com a possível inexistência dos requisitos, ou pressupostos, da constituição da relação processual válida. É situação que diz respeito apenas ao exercício do direito de ação e que pressupõe a autonomia desse direito. Incumbe ao juiz, antes de entrar no exame do mérito, verificar se a relação processual, que se instaurou, desenvolveu-se regularmente (pressupostos processuais) e se o direito de ação pode ser validamente exercido, no caso concreto (condições da ação).

Percebe-se, nesse ponto, a superação, em certa medida, da doutrina de Liebman, ainda entre aqueles que verificam no Código de Processo Civil de 2015 os requisitos interesse e legitimidade como condições da ação. Na sistemática apregoada por Liebman (2005), esses elementos constituem, propriamente, pressupostos essenciais à própria existência do direito de ação e à atuação do órgão jurisdicional. A despeito, as construções que a doutrina pátria se permitiu realizar viabilizaram o exame da ação por novas linhas. É papel das condições da ação, nesse panorama, instrumentalizar o exercício regular da ação no âmbito processual, possibilitando, desde que exista uma relação jurídica processual válida, e que a pretensão se ligue de certa forma com a lide, a análise do mérito (Freire, 2001).

Por esses tantos, a doutrina das condições como de existência da ação, perdeu espaço. Com a propositura da demanda, a parte exerce efetivamente seu direito de ação e retira da inércia o órgão jurisdicional. Diante a não evidenciação de pressupostos de ordem técnica, é negada à parte a tutela pretendida, mediante a extinção prematura da relação processual. Isto, nas palavras de Theodoro Júnior (2017, p. 160-161), já constitui, por sua natureza, reflexo da atuação jurisdicional, “[...] pois ao processo compete não só propiciar instrumento à realização da tutela jurisdicional, como de controle da necessidade ou cabimento da tutela efetivamente pretendida pela parte $[\ldots .$.$] ".$

Apesar disso, a clássica lição de Liebman ainda guarda admiradores entre os juristas brasileiros. Dinamarco, partidário histórico do processualista italiano, e Lopes, mantêm-se fiéis à doutrina das condições da ação como requisitos de existência da ação. De acordo com estes processualistas: "as condições da ação constituem requisitos sem os quais o direito de ação inexiste em dado caso concreto" (Dinamarco \& Lopes, 2018, p. 116). E, por conseguinte, concluem: "em falta de uma das condições da ação ou de ambas (interesse e necessidade) diz-se que o autor é carecedor de ação, ou seja, que ele não tem o direito de ação em dado caso concreto [...]. E, por não ter o autor direito de ação, o mérito da causa não pode ser julgado [...]" (2018, p. 118).

Por todas as orientações apresentadas, relevante trazer à baila pertinente crítica de Araújo (2016). A partir de sua larga experiência na magistratura, apresenta o jurista que a maioria das decisões proferidas com fundamento na carência de ação são 
reformadas, e, constata que isto se dá, justamente, por serem indissociáveis do mérito. Defensor da conjectura de que, no exercício de cognição do juiz, haveriam somente duas ordens de questões a serem analisadas (pressupostos processuais e mérito), descreve que, em sistemas infensos à categoria das condições da ação, a inexistência de legitimidade ad causam, ao invés de dar causa à extinção do processo sem resolução do mérito, por carência de ação, “[...] seria causa para julgamento liminar de improcedência, com análise do mérito, propiciando a estabilização da demanda", de modo que "[...] a natureza instrumental do processo é reforçada e a efetividade do processo otimizada [...]" (Araújo, 2016, p. 343).

Verifica-se que o cenário jurídico brasileiro se encontra distante em constituir um consenso a respeito dos movimentos legislativos em torno dos requisitos interesse e legitimidade. E deste cenário não se pode colher frutos negativos. A diversidade de orientações ultrapassa as barreiras teórico-doutrinárias, e representa a guinada dos juristas atuais em instrumentalizar e imprimir efetividade aos institutos processuais.

De mais a mais, ainda que, por vezes, direcionem-se em sentidos totalmente diversos, evidencia-se que as doutrinas atuais priorizam os resultados práticos dos institutos jurídicos em geral, sobremaneira o sob análise. Isto se dá visando a adequação dos instrumentos processuais às necessidades da prestação jurisdicional, privilegiando a efetivação dos direitos a partir do acesso à justiça pleno e à ordem jurídica justa.

\section{Conclusão}

A promulgação do Código de Processo Civil de 2015 constitui reflexo de uma longa contenda do Direito brasileiro, com expressivo papel do Estado-legislador, no intento de edificar um processo que, acima de tudo, represente um verdadeiro expediente de justiça. Nessa toada, a nova codificação emergiu no plano jurídico imerso em novas perspectivas do direito processual, as quais se distanciam da velha dogmática jurídica e se destina a imprimir a máxima instrumentalidade e efetividade aos instrumentos jurídicos processuais.

Sob esses paradigmas, imperativo visualizar o fenômeno da ação teleologicamente. Mas, por teleológico, deve-se compreender muito além de puros resultados. Resultados adequados implicam a observância dos meios pertinentes à efetiva prestação jurisdicional. Destarte, o direito de ação implica em um complexo de posições jurídicas que asseguram aos jurisdicionados o acesso à tutela jurisdicional adequada, ou seja, constituir verdadeiro meio à realização do direito material, efetiva, ao ponto de ser apta a inibir ameaças à direito e resguardar direitos violados, e tempestiva, pois justiça tardia resta a esmo de seu próprio fim, tendo como alicerce todos os direitos e garantias decorrentes ao devido processo constitucional.

É a partir dessas premissas que o jurista deve se debruçar sobre os institutos processuais. O legislador do Código de Processo Civil de 2015 conferiu aos elementos interesse e legitimidade nova fisionomia, em contrapartida ao assentado pelo legislador do Código de 1973. Quando da promulgação do Código revogado, o cenário processual brasileiro absorvia indistintamente a teoria da ação apregoada por Liebman. Dessa forma, no texto do códex, o legislador inseriu os elementos em destaque como espécies da categoria das condições da ação, nos exatos termos apregoados pelo mestre italiano, o qual identificava os requisitos interesse e legitimidade - ao lado da possibilidade jurídica do pedido - como verdadeiros condicionantes à existência da ação.

Nada obstante, o Código de Processo Civil atual emergiu no plano jurídico influenciado por novos paradigmas doutrinários, infenso, em certa medida, ao conceitualismo, e tendente à instrumentação da tutela jurisdicional. Por conseguinte, as expressões que, no regime anterior, caracterizavam cabalmente a adoção pelo legislador da categoria autônoma das condições da ação foram deixadas de lado. Atualmente, apenas adverte o Código que, para postular em juízo, é necessário interesse e legitimidade e estabelece como resultado da ausência de um, ou ambos, desses elementos, hipótese de negação pelo Estado-juiz da solução da lide levada à sua apreciação. 
Neste ponto cinge-se o acerto inegável do legislador. No regime anterior, a adoção pelo legislador de modelo doutrinário implicou em verdadeiro engessamento do plano jurídico, impedindo o desenvolvimento do Direito, enquanto instituição. Isto porque obstruiu a esfera de discricionariedade da doutrina e jurisprudência em extrair das fontes a norma mais adequada ao momento jurídico em que se encontra o ordenamento jurídico. De mais a mais, o Código vigente, ao estabelecer os institutos com as linhas postas, permitiu o desenvolvimento natural dos institutos e a atuação positiva da doutrina e da jurisprudência, os quais possuem a aptidão para moldar os institutos de acordo com a necessidade da prestação jurisdicional.

Esse panorama favoreceu o desenvolvimento da doutrina de diversas orientações relativas às afeições dos requisitos interesse e legitimidade sob a égide do Código de Processo Civil atual. As formulações se distanciam de formar verdadeiro consenso, e, por vezes, norteiam destinos deveras diversos. E a divergência em si não deve ser identifica negativamente. Se, por um lado, a dissonância teórica é marcadamente expressiva, a convergência entre os juristas é ainda mais eloquente, a qual se evidencia da tenacidade em atribuir a maior efetividade à tutela jurisdicional.

Sem embargo, é possível colher que as formulações apregoadas são produto da concepção particular dos processualistas sobre o provimento jurisdicional que mais eficientemente é apto a atender a função natural da jurisdição. Entre aqueles que associam os requisitos interesse e legitimidade à consagrada categoria das condições da ação, a extinção prematura do processo diante a inexistência de vínculo entre a situação jurídica afirmada é a mais adequada, pois impede o prosseguimento de processos infundados, assim atendendo, a jurisdição, com maior presteza o fim a que se destina.

Por outro, os que aproximam os elementos em destaque ao meritum causae, a efetividade processual se situa na estabilização da demanda. Por conseguinte, cabe ao juiz, sempre que possível, colocar termo à crise levada a sua apreciação mediante uma decisão definitiva.

Dito isso, verifica-se, inobstante os meios diversos, as construções doutrinárias que circunscrevem os requisitos interesse e legitimidade tendem à adequação necessária a garantir aos cidadãos o acesso à justiça pleno, e que lhes assegure o livre desenvolvimento de sua personalidade, tendo como sustentação os direitos fundamentais.

Nessa tarefa, não se faz relevante determinar precisamente qual a direção que o Código de Processo Civil em vigor prioriza, adotando-se orientação doutrinária específica, mas conciliar as concepções dos juristas pátrios, de modo a conferir aos elementos interesse e legitimidade, na nova ordem, a interpretação adequada a garantir aos jurisdicionados o acesso à tutela jurisdicional em sua plenitude.

Por fim, quanto à futuros estudos sobre os institutos interesse e legitimidade, cumpre, porquanto elementos da técnica processual, ordená-los de acordo com os propósitos processuais, máxime o acesso à ordem jurídica justa. Ademais, comprometida com os escopos processuais, releva pesquisa de ordem jurisprudencial, tendente a analisar, a partir da experiência, as repercussões decorrentes da incidência dos elementos interesse e legitimidade na prestação jurisdicional, inclusive quanto ao momento e condições adotados pelo poder judiciário para apreciá-los.

\section{Referências}

Alvim, A. (1990). Tratado de direito processual civil (2 ed., v. 1). São Paulo: Revista dos Tribunais.

Araújo, F. C. de. (2016). Curso de processo civil: parte geral - Atualizado com a Lei 13.256/2016 (t. 1). São Paulo: Malheiros.

Baracho, J. A. de O. (jul.-dez. 2004). Teoria Geral do Processo Constitucional. Revista Brasileira de Estudos Políticos, Belo Horizonte, 90, 69-170. https://pos.direito.ufmg.br/rbep/index.php/rbep/article/view/4/3

Bedaque, J. R. dos S. (2010). Efetividade do processo e técnica processual (3ª . ed.). São Paulo: Malheiros.

Bueno, C. S. (2018). Manual de direito processual civil (4a. ed.). São Paulo: Saraiva.

Buzaid, A. (jan. 1977). A influência de Liebman no direito processual civil brasileiro. Revista da Faculdade de Direito, Universidade de São Paulo, São Paulo, 72(1), 131-152. https://www.revistas.usp.br/rfdusp/article/view/66795 
Câmara, A. F. (jul. 2011). Será o fim da categoria “condições da ação”? Uma resposta a Fredie Didier Junior. Revista de Processo, São Paulo, 36(197), p. 261269.

Cappelletti, M., \& Garth, B. (1988). Acesso à justiça. (Northfeet, E. G. Trad.) Porto Alegre: Fabris.

Chiovenda, G. (1942). Instituições de direito processual civil (Menegale, J. G. Trad.) (v. 1). São Paulo: Saraiva \& Cia.

Chiovenda, G. (1943). Instituições de direito processual civil (Menegale, J. G. Trad.) (v. 2). São Paulo: Saraiva \& Cia.

Couture, E. J. (1946). Fundamentos do Direito Processual Civil (Souza, R. G. de. Trad.). São Paulo: Saraiva \& Cia.

Cunha, L. C. da. (ago. 2011). Será o fim da categoria condições da ação? Uma intromissão no debate travado entre Fredie Didier Jr. Alexandre Freitas Câmara. Revista de Processo, São Paulo, 36(198), p. 227-236.

Didier Júnior, F. (2016). Curso de direito processual civil: introdução ao direito processual civil, parte geral e processo de conhecimento (18 ${ }^{\mathrm{a}}$. ed. v. 1), Salvador: JusPodivm.

Didier Júnior, F. (jul. 2011). Será o fim da categoria "condição da ação"? Um elogio ao projeto do novo Código de Processo Civil. Revista de Processo, São Paulo, 36(197), p. 255-260.

Dinamarco, C. R. (2001). A reforma do Código de Processo Civil (5 . ed.). São Paulo: Malheiros.

Dinamarco, C. R. (2002). Fundamentos do processo civil moderno. São Paulo: Malheiros.

Dinamarco, C. R. (2004). Instituições de direito processual civil (4ª ed., v. 2). São Paulo: Malheiros.

Dinamarco, C. R., \& Lopes, B. V. C. (2018). Teoria geral do novo processo civil (3ª ed.). São Paulo: Malheiros.

Freire, R. da C. L. (2001). Condições da ação: enfoque sobre o interesse de agir (2ª ed.) São Paulo: Revista dos Tribunais.

Gil, A. C. (2009). Como elaborar projetos de pesquisa (4ª . ed.). São Paulo: Atlas.

Gil, A. C. (1999). Métodos e técnicas de pesquisa social (5ª ed.). São Paulo: Atlas.

Gomes, F. (1999). Carência de ação: doutrina, comentários ao CPC, análise da jurisprudência. São Paulo: Revista dos Tribunais.

Gonçalves, A. P. (1992). Técnica processual e teoria do processo. Rio de Janeiro: Aide.

Grinover, A. P. (2011). O direito de ação. In Wambier, L. R. (Org.) \& WAMBIER, T. A. A. (Org.). Teoria geral do processo I (Coleção Doutrinas Essenciais, v. 2, 45-57). São Paulo: Revista dos Tribunais.

Grinover, A. P. (jan. 1986). O magistério de Enrico Tullio Liebman no Brasil. Revista da Faculdade de Direito, Universidade de São Paulo, São Paulo, 81, 98-102. https://www.revistas.usp.br/rfdusp/article/view/67069

Grinover, A. P. (1977). As condições da ação penal: uma tentativa de revisão. São Paulo: Bushatsky.

Lacerda, G. (1985). Despacho saneador (2ª . ed.). Porto Alegre: Fabris.

Leal, R. P. (2008). Teoria geral do processo: primeiros estudos (7ª ed.). Rio de Janeiro: Forense.

Liebman, E. T. (1947). Estudos sobre o processo civil brasileiro. São Paulo: Saraiva \& Cia.

Liebman, E. T. (2005). Manual de direito processual civil (Dinamarco, C. R. Trad.) (3ª . ed., v. 1). São Paulo: Malheiros.

Marconi, M. de A., \& Lakatos, E. M. (2010). Fundamentos da metodologia científica (7ª ed.). São Paulo: Atlas.

Marinoni, L. G., Arenhart, S. C., \& Mitidiero, D. (2016). Novo curso de processo civil: teoria do processo civil (2a. ed., v. 1). São Paulo: Revista dos Tribunais.

Medina, J. M. G. (2016). Direito processual civil moderno (2ª ed.). São Paulo: Revista dos Tribunais.

Medina, J. M. G. (2014). Novo CPC não deve adotar conceito sobre condições para a ação. Consultor Jurídico, São Paulo, 25 ago. https://www.conjur.com.br/2014-ago-25/cpc-nao-adotar-conceito-condicoes-acao

Mesquita, J. I. B. de. (1975). Da ação civil. São Paulo: Revista dos Tribunais.

Nader, P. (2001). Introdução ao estudo do direito. Rio de Janeiro: Forense.

Nery Junior, N., \& Nery, R. M. de. (2018). Código de Processo Civil comentado (17. ed.). São Paulo: Revista dos Tribunais.

Neves, C. (1997). Estrutura fundamental do processo civil: tutela jurídica processual, ação, processo e procedimento. Rio de Janeiro: Forense.

Oliveira, E. R. de. (2011). Condições da ação: a possibilidade jurídica do pedido. In Wambier, L. R. (Org.) \& Wambier, T. A. A. (Org.). Teoria geral do processo I (Coleção Doutrinas Essenciais, v. 2, 135-147). São Paulo: Revista dos Tribunais.

Saldanha, J. M. L. (2010). A paradoxal face "hipermoderna" do processo constitucional: um olhar sobre o direito processual brasileiro. Revista Estudios Constitucionales, Santiago, 8(2), 675-706. http://www.estudiosconstitucionales.cl/index.php/econstitucionales/article/view/196/184 
Research, Society and Development, v. 10, n. 13, e255101321192, 2021

(CC BY 4.0) | ISSN 2525-3409 | DOI: http://dx.doi.org/10.33448/rsd-v10i13.21192

Severino, A. J. (2007). Metodologia do trabalho científico (23 ${ }^{\mathrm{a}}$. ed.). São Paulo: Cortez.

Thamay, R. F. K. (2016). Condições da ação no novo CPC. Revista Jurídica Luso-Brasileira, Lisboa, 2(3), 1243-1268. Recuperado de https://www.cidp.pt/revistas/rjlb/2016/3/2016_03_1243_1268.pdf

Theodoro Júnior, H. (2017). Curso de Direito Processual Civil: teoria geral do direito processual civil, processo de conhecimento e procedimento comum (58. ed. v. 1), Rio de Janeiro: Forense.

Theodoro Júnior, H. (out.-nov. 2009). Direito processual constitucional. Revista Estação Científica (Ed. Especial Direito), Juiz de Fora, 1(4), 28-43. http://portal.estacio.br/media/4301/artigo-2-revisado.pdf

Vidigal, L. E. de B. (1986). Enrico Tullio Liebman e a processualística brasileira. Revista da Faculdade de Direito, Universidade de São Paulo, São Paulo, 81, 103-112. https://www.revistas.usp.br/rfdusp/article/view/67070

Wambier, L. R., \& Talamini, E. (2016). Curso avançado de processo civil: teoria geral do processo (16. ed.). São Paulo: Revista dos Tribunais. 